Journal of the British Association for Chinese Studies, Vol. 9 (1), January 2019

ISSN 2048-0601

(C) British Association for Chinese Studies

\title{
Portrayals of the Chinese Être Particulières: Intellectual Women and Their Dilemmas in the Chinese Popular Context Since 2000
}

\author{
Meng Li \\ The Hong Kong Polytechnic University
}

\begin{abstract}
This article studies the tension between post-Mao Chinese intellectual women and their dilemma in post-2000s Chinese popular media. TV dramas, films, songs and reality shows in which Chinese intellectual women and their dilemmas are identified, mis/represented, mis/understood and addressed are the research objects of this article. By foregrounding the two motifs of estrangement and escape in understanding and characterising post-Mao Chinese intellectual women, the article seeks to answer the following questions: In what ways are well-educated Chinese women consistently stigmatised under the unsympathetic limelight of the public? And for what reason are Chinese intellectual women identified as the être particulières in the popular context?
\end{abstract}

Keywords: intellectual women, dilemma, estrangement, escape, popular cultural context.

The article is partly developed from the postscript of my unpublished PhD thesis (Li, 2013). I thank my supervisors Professor Catherine Driscoll, Professor Yiyan Wang, as well as the two anonymous reviewers for their constructive suggestions to this article. 
Efforts to define the femininity of intellectual women and explain why intellectual women, "une être particulière" (Ernot, 1998: 102, cited in Long, 2013: 13), are exposed to stigmatisation has been the focus of my research of the previous decade. Both Luce Irigaray (1985) and Chen Ya-chen (2011) have proposed viewing female desire and language, as well as feminism itself, via a multi-dimensional lens. Their proposal has received active responses from Chinese intellectual women. Such responses can be seen via the prevailing multi-dimensional perspective in understanding issues of Chinese women and gender in the last three decades (Tong, 2008: 68). My research defines "intellectual women" as women with higher education who demonstrate independent thinking and feminist self-consciousness in their intellectual activities. These intellectual activities, to adopt Antonio Gramsci's categorisation, enable these women to become "creators of the various sciences, philosophy, art" and "'administrators' and divulgators of pre-existing, traditional, accumulated intellectual wealth" (Gramsci, cited in Gottlieb, 1989: 119). Therefore, instead of viewing intellectual women in terms of another influential Gramscian demarcation of the "organic intellectuals" and "traditional intellectuals", this article specifically identifies female professionals, artists, writers, academics, and students pursuing or holding college degrees or higher qualifications as intellectual women.

Timothy Cheek's monograph on the narrative history of Chinese intellectuals meticulously categorises intellectuals from 1996 to 2015 (who are unanimously male) as establishment intellectuals, academic/public intellectuals and independent intellectuals (Cheek, 2016: 267). His lucid demarcation of postMao Chinese intellectuals invites comprehensive understanding of intellectual activities in contemporary China. Rather than adopting his demarcation, this article focuses on the portrayals of intellectual women's activities in what Cheek names "the many worlds of Chinese intellectuals" (2016: 280): the official world 
(which I understand as the tension they experience with the State-imposed discourse in marriage, birth and family values), the commercial world (how intellectual women are consumed as targets of mockery in popular media), and the academic world (how intellectual women are portrayed as undesirable in the marriage market due to their high level of academic achievement). ${ }^{1}$ The portrayals of intellectual women in these three worlds puts them in a dilemma, or, to use Cheek's words, in "the lonely world of dissent" (2016: 285).

The dilemma of post-Mao Chinese intellectual women is situated at the intersection of the dilemmas of the post-Mao Chinese intellectual and that of Chinese women. The dilemma of Chinese intellectuals merges the coexistence of the pride and privileges granted by epistemological advantage and cultural capital (Xu, 2016: 45-46), and with tensions with state ideology. The relationship between post-Mao Chinese intellectuals and state ideology is often marked by uncomfortable marginalisation in both the political and cultural senses (Yu, 2003). ${ }^{2}$ This marginalisation is coupled with anti-intellectualism, a haunting political tradition in Chinese history from the Maoist era to the post-Mao era (Cheek, 2016: 278-9). Anti-intellectualism, with its implications of hatred, doubt, discrimination and even hostility is against the intellect and intellectuals (Yu, 2014: 2). When the above-mentioned dilemma incorporates Chinese women's struggles against sexism, staggering negotiation between both modern and traditional gender norms, as well as state-imposed gender and marriage ideals,

\footnotetext{
${ }^{1}$ In Cheek's study, all value spheres of Chinese intellectuals of the period 1996 and 2015 include: "the official world of public and political life; the academic world of universities and scholarship; the commercial world of making, buying and selling; the associational world of public intellectuals, religious groups, Internet communities, non-governmental organizations (NGOs) and other tolerated groups; and [...] the waiyu world of 'foreign language communities'"' (2016: 273). He also includes discussion of "the lonely world of open dissent" (2016:285).

${ }^{2}$ A similar argument can be found in Mok Ka-ho's Intellectuals and the State in Post-Mao China. Mok sees a lowered social position of post-Mao Chinese intellectuals and he argues that the post-Mao Chinese intellectuals remain "appendages of the working class". See Mok (1998: 201).
} 
a gendered and intensified version of the plight of Chinese intellectuals results: the dilemma of Chinese intellectual women.

In my previous research on the fiction of the female writer Huang Beijia, which largely focuses on the lives of intellectual women characters, I foregrounded two motifs which characterise the subjectivity of Chinese intellectual women: estrangement and escape (Li, 2013: 87). I also proposed that these two motifs can be the lens through which the femininity of Chinese intellectual women can be understood (Li, 2013). My next step in the study of Chinese intellectual women will present how the tension between intellectual women and their dilemma is manifested via estrangement and escape. Both estrangement and escape are associated with certain characteristics of intellectuals including outsidership and an autonomous and precarious status. These qualities are captured in terms such as "free-floating intelligentsia" (Mannheim, 2000: 159), 3 Sartrean solitary self-orientation as "hav[ing] no mandate from anyone but ow[ing] his status only to himself" (Sartre, 1972: 44, cited in Long, 2013: 19), the metaphoric "strangerhood" (Pels, 2013: 193) and "privileged nomads" (Pels, 2013: 176), and the romanticised model of "powerless exiles" (Said, 1994: 47). These characterisations enable intellectuals' detachment from any class as well as their formation into a single class. Their remoteness, detached position or experience of distance thus allow intellectuals to broaden their view in society and life (Mendel, 2006:38-9).

As for intellectual women, such detachment is, from a feminist perspective, intensified by women's marginal position in patriarchal society. Therefore, Pels' salient understanding of intellectual women's location of inbetweenness maps

\footnotetext{
3 In her study on Mannheim's "free-floating intelligentsia", Iris Mendel similarly states that intellectuals are a "heterogeneous collective whose social and political position is difficult to locate". See Mendel (2006: 34).
} 
out the dilemma of being an intellectual woman:

It is her peculiar intermediate condition of an outsider within, her distance position of marginality in the centre and the double consciousness which is induced by it, which is taken metonymically to reflect the standpoint of the "class" of women as a whole (Pels, 2013: 165).

My proposal of the term "estrangement" is a continuation of Pels' concept. Estrangement emphasises the status of "being different" and "being away" from others. It emphasises the pride of the intellectual, which centres on their role as the knowledge elite. My research on estrangement foregrounds two perspectives of intellectual women: one is the self-orientation of intellectual women, and the other is the way they are viewed in different cultural discourses and contexts. Both perspectives demonstrate intellectual women's selfidentities, as well as identities imposed by others.

From the perspective of self-orientation, intellectual women highlight their own superiority through their education and knowledge, ideals, lifestyle and taste. This estrangement also functions in intellectual women's negotiations with the Confucian, Maoist and post-Mao discourses in which they orient themselves even as they are viewed externally as "different" for distancing themselves from the dominant discourse.

Escape accentuates what intellectual women actually do with their lives which manifest their independence and their autonomy/subjectivity. Escape also involves two dimensions: one is the way intellectual women emancipate themselves in the form of escape while the other focuses on their physical and social mobility, including Chinese intellectual women's connection to the West. 
In the first dimension, intellectual women seek emancipation from thebinds of family, marriage, and gender conformity which bespeak the patriarchal order. In the dimension of escape, intellectual women in the post-Mao popular cultural context can often be seen performing their escape by imagining, consuming and attempting a "life elsewhere", notably in engagement with the West (Li, 2013).

This article studies the tension between Chinese intellectual women and antagonism toward intellectual women as represented in the popular context in post-2000s China. It renders this animosity not just as hatred against woman. It will demonstrate that the ill feeling towards intellectual woman comes from both men and other women, who are, in the words of Sartre cited in the epigraph in the second volume of Simone de Beauvoir's The Second Sex, "[h]alf victims, half accomplices, like everyone else" (Sartre, 1955: 189). The remainder of this article illustrates the adaptability of the two motifs in the post-2000s Chinese popular media. In what follows, I first offer a comparative study of the intellectual women protagonists in the films The Postmodern Life of My Aunt (Yima de houxiandai shenghuo 姨妈的后现代生活, 2006, dir. Ann Hui), ${ }^{4}$ and And the Spring Comes (Lichun 立春，2007, dir. Gu Changwei). Both films characterise intellectual women in related ways, illustrating the tentative social status they secure in difficult situations.

The second section maps out the unfriendly and sometimes prejudicial portrayals of intellectual women in the popular media since the 2010s. I argue that these labels and metaphors of vilification underscore intellectual women's estrangement. Seasoned cynically with pretentious self-depreciation, "Song of an Elder Artistic Woman” (Daling wenyi nü qingnian zhi ge 大龄文艺女青年之

\footnotetext{
${ }^{4}$ Due to her identity as a Hong Kong filmmaker, Ann Hui's cinematic representation of Chinese intellectual women is sometimes questioned by Chinese critics and audiences. The focus of this article, however, is the representation rather than the verisimilitude
} 
歌), the signature song of folk singer Shao Yibei, will be read as a fight-back against the animosity targeted at intellectual women.

\section{Bitter Cinematic Representations of Intellectual Women in The Postmodern Life of My Aunt and And the Spring Comes}

In this section, I present a comparative analysis of two representations of postMao intellectual women in early twenty-first century Chinese cinema: the characters Ye Rutang in Postmodern Life of My Aunt and Wang Cailing in And the Spring Comes. Both films feature intellectual women as dreamers, placing them in situations in which they struggle to manifest their subjectivity as intellectual women. In many ways, both films represent intellectual women as misfits, and such representations intensify the bitterness and poignancy shared by these female characters. Here, these films are read in light of the proposed two motifs, estrangement and escape.

In The Postmodern Life of My Aunt, Ye Rutang (Aunt Ye) leaves her construction worker husband and baby daughter in the industrial city of Anshan in the early years of the reform era. She lives alone in metropolitan Shanghai, earning a living as a freelance English tutor. After having led years of a middleclass lifestyle, the retired woman then has her lifelong savings stolen by her lover. Now bankrupt, she returns to Anshan to live with her husband, with whom she sells leather shoes in the local flea market. The female protagonist Wang Cailing in Gu Changwei's And the Spring Comes is a college vocal teacher in a backwater town. She has ambitions of becoming an acclaimed soprano and endeavours to be selected to join the National Opera in Beijing. She is disgraced by her attempt at a romantic relationship with a like-minded frustrated young artist. Her dreams crushed, Wang abandons her singing career and opens up a 
butchery.

Both Ye and Wang are well-educated intellectual women who distinguish themselves through their refinement in what Theodore Adorno may define as "high culture". In the case of Ye, it is her predilection for Peking Opera, Chinese painting, horticulture and exquisite connoisseurship of food, and for Wang, her love of Italian operas, Schubert's Lieder and $19^{\text {th }}$ century Russian literature. Their artistic and cultural engagements are for the most part unappreciated and misunderstood by the supporting characters of the films. Wang is portrayed as a character of contradictions. Her dark complexion, freckles and pointed teeth typecast her as being not sexually attractive to men. In contrast to her unpleasant appearance, she has a mellifluous voice. Wang is therefore characterised as what Luce Irigaray may see as not "within the discourse of truth," which maintains that "the feminine occurs only within models and laws devised by male subjects" (Irigaray, 1985: 86). Wang's colleagues and neighbours have little knowledge of the Western operatic works she sings; nor is she willing to communicate with them. She voices her disappointment in being a well-educated woman of refined taste in such a small town by quoting Anton Chekov's play Three Sisters, stating that "in this city, knowing three languages is an unnecessary luxury. Not even a luxury, an unnecessary appendage, like a sixth finger" (Chekov, 2014: 15). 


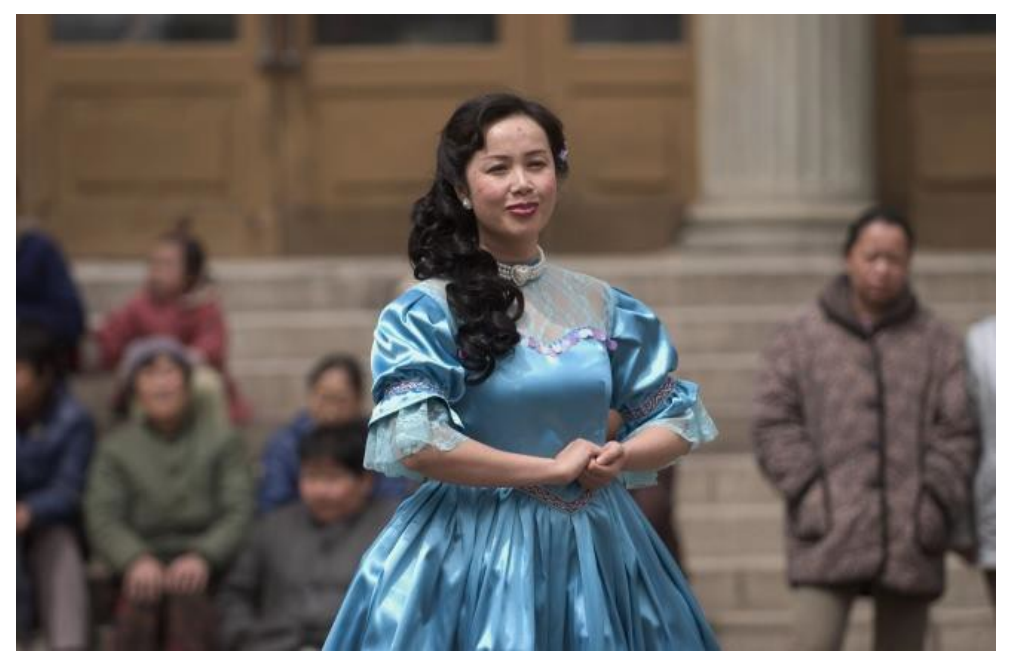

Figure 1: Wang sings Mendelssohn's On the Wings of Songs in the public square of her town. Her luxurious Westernised costume and hairstyle put her in great contrast to her audience, whose clothing signifies a less-modernised status (see KKNews, 2017a).

In The Postmodern Life of My Aunt, Ye's estrangement is overtly suggested by the title "postmodern", which already highlights her contesting subjectivity against established gender norms and traditions across the Maoist and PostMao Eras. Focusing on Ye's fractured identities, Gina Marchetti treats Ye as a "post-feminist", a concept which originally refers to women in the Western world but could also be applied in a contemporary Chinese context (Marchetti, 2009: 135). As a dominant social, cultural and commercial discourse in contemporary society, especially the West, post-feminism invites a multiplicity of interpretations and is characterised by an ambiguity fraught with contradictions, conflicts and uncertainty (Holmes et al., 2011: 180). This ambiguity is a typical hallmark of the discussion of postmodernism, which is elusive in its acceptance of multiplicity, ambiguity, contradiction, uncertainty, 
chaos and conflicts (Bordo, 1993: 40), as well as in its celebration of schizophrenic fragmentations as fundamental aesthetics (Jameson, 2013: 28).

The post-feminist and neoliberal situation of contemporary China exacerbates the dilemma of the intellectual woman. Though Marchetti does not identify or stress this aspect of Ye's identity, her discussion is relevant to my emphasis. Marchetti points out that Ye has clearly demonstrated a fragmented gender role incompatible with the Confucian ideal of womanhood, the market economy and socialism feminism (Marchetti, 2009: 124, 137-8). Ye has obviously benefited from the post-1949 changes in gender roles, and has an enviable education and a comfortable home in urban Shanghai. What makes Ye "postmodern" and "post-Mao" is her disorientated life trajectory, which appears in the eye of her nephew Kuankuan (who is the witness of Ye's life) as unconventional and weird.

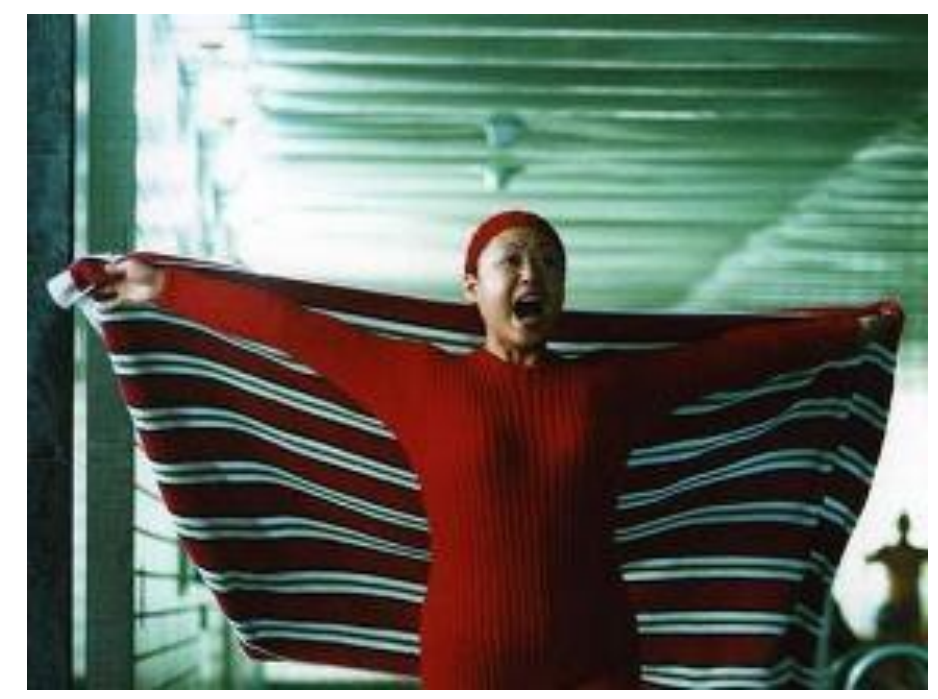

Figure 2: Ye proudly sports her full-body swimsuit, which is designed and knitted by herself (see Baike, 2015). 
Another dimension of Ye's estrangement lies in her retirement and financial independence. Ye's retirement ensures her ample spare time to engage in her fine tastes, and her well-paid job as an English tutor signifies financial independence. The enjoyment of leisure time and a financially independent existence signifies a leisure-class existence, which, according to Mannheim, is "a source of estrangement from reality, for it conceals the frictions and tensions of life and invites a sublimated and internalised perception of things" (Mannheim, 1968: 160).

Ye's status as a university graduate is important to her characterisation in the film. After graduation, she moves to the northern industrial city Anshan as an educated youth and marries a factory worker. This marriage is an ideal one for the dominant ideology of the Maoist era. According to Mao, educated youth needed to be "re-educated" by the proletariat masses (i.e. peasants, workers and soldiers). Therefore, marriage to a member of the proletariat was considered a repudiation of the "filthy" intellectual class (White, 1998: 413). However, Ye is unsatisfied with her marriage. After the end of the Cultural Revolution, when educated youth were again granted the opportunity to work in urban areas, Ye leaves her baby daughter and husband behind, later cutting contact with them altogether. In this sense, Ye's escape from her husband shows her repudiating the traditional role of mother and wife, instead allowing her to perform her subjectivity as an intellectual woman.

Escaping from her family, Ye settles alone in the metropolis of Shanghai, working as a private English tutor. In Shanghai, Ye performs her estrangement from expectations of women by means of her own elite cultural tastes and behaviours. She demonstrates her high-brow taste via her appreciation of Chinese paintings and Peking opera. She looks down upon her neighbours, whom she calls "badly educated", thinking that no one could match her 
intellectually. Ye is extremely annoyed by her next-door neighbour, Mrs Shui, who constantly showcases her material affluence. When her nephew Kuankuan mocks Ye for being jealous of Mrs Shui, Ye is infuriated. She proclaims her dignity as an intellectual and former model-worker:

The people in this building are all wretches. Very few are college students! Unlike me! I used to win "Model Worker" awards every year! Everyone sang my praises. She's just rich. So what's she good for? [...] I've always lived an upright life $\left(10^{\prime} 12^{\prime \prime}-10^{\prime} 36^{\prime \prime}\right)$.

Here, Ye defines her superiority by means of cultural capital defined by her educational practices ("products of learning"), and her preference of high culture (Bourdieu, 1996: 29), whereas Mrs Shui does the same by means of her display of affluence and economic capital, which Ye does not possess.

Ye's estrangement also brings about embarrassing moments of social interaction. Like the discerning Wang Cailing, Ye, who works as a private English tutor, is proud of her British accent, which she deems "more tasteful [than an American accent]" (18'44"). Yet, she is fired by her employer who insinuates that her high taste is a mismatch for contemporary Chinese society. "Yes," he says, "so is classical Chinese. But who speaks that now?" (18'55"). This scene echoes with Marchetti's remark that Ye could not be identified as a "paragon of socialist feminism: her independence hides her isolation, her education seems out of touch with the marketplace", and instead she is "the contradictory representative of modern, urban, enlightened Shanghai and the decaying dreams of the 'rust belt' of the Northeast" (Marchetti, 2009: 124). It is evident that $Y e$ is estranged from the prevalent value of the market-oriented economy of post-Mao China. 
The romantic experiences with men enacted by the female characters in these films intensify their estrangement and ultimately their suffering. In both films, romantic adventures conclude bleakly. In The Postmodern Life of My Aunt, Pan Zhichang (Chow Yun-fat) fulfils Ye's fantasy of an ideal romantic partner by means of his cultural refinement. He is also the same person who cheats away her lifelong savings. In And the Spring Comes, Wang's romantic expressions are shared by three male dreamers: Huang Sibao the self-taught artist, Zhou Yu, the ambitious amateur singer, and Hu Jinquan, the ballerino.

Gu Changwei, director of And the Spring Comes, seems to favour the romance between Wang and Huang Sibao, the young frustrated artist of all of the heterosexual romances that the female protagonist is involved in. The scene in which Wang poses for Huang, his first opportunity to paint a nude (figure 3), is used as the film's selling point and is often shown in the film's promotional posters (figures 3 and 4).

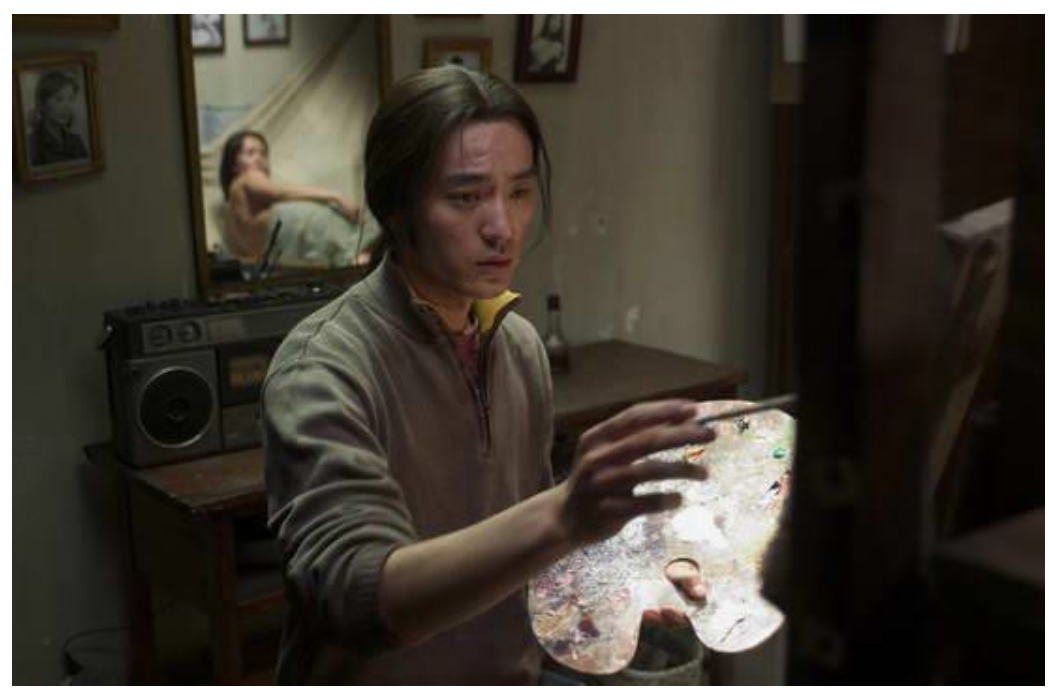

Figure 3: Wang poses for Huang (see Sina, 2008). 


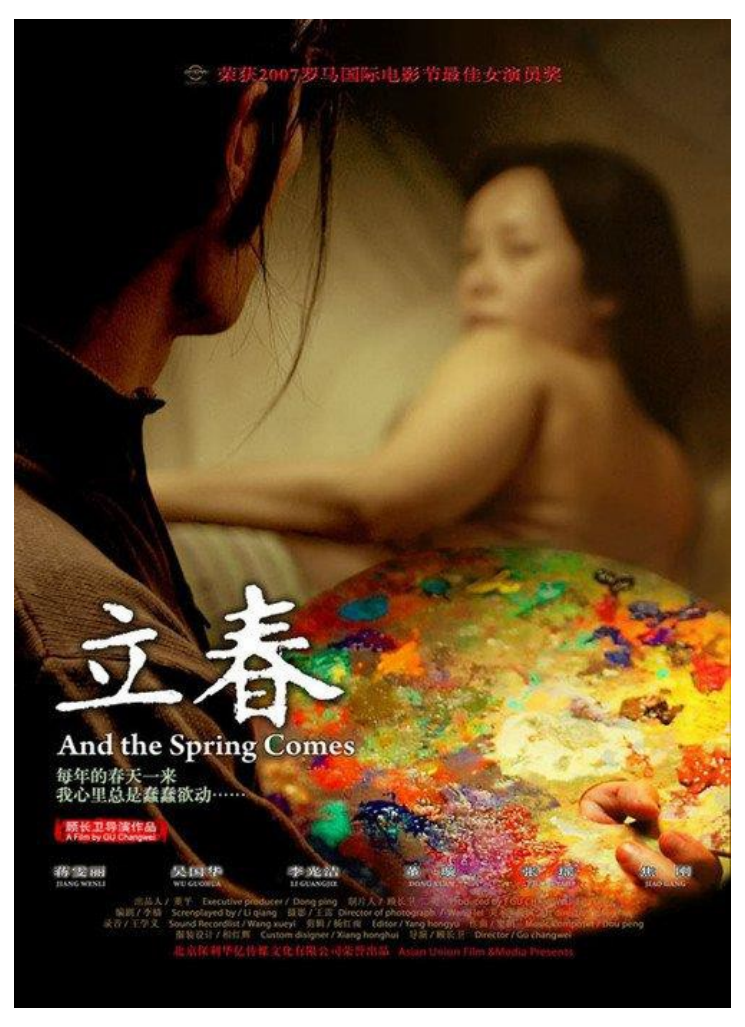

Figure 4: The official poster of And the Spring Comes (see Alchetron, 2018).

Before meeting Huang, Wang considers none of the locals a suitable match for her on an intellectual level. Huang, who dreams of becoming the next Vincent van Gogh, has failed several times in gaining admittance to study at the Central Academy of Fine Arts in Beijing. He comes to visit Wang after hearing about her connections to Beijing. Like Wang, Huang finds it impossible to realise his big dream in the small town where he makes a living as a factory worker. Exhilarated by this spiritual bond, Wang poses for Huang and even contemplates procuring Beijing citizenship for him with her own savings. Wang considers herself attractive to the young artist who, however, is more interested in her connections with Beijing. Wang has her first ever sexual experience with 
Huang on the night when he rushes into her place, heavily drunk, weeping about his failure at becoming an artist.

Afterwards, Wang consciously dresses up with make-up and a silk scarf, which she never does in previous scenes. This change draws attention to Beauvoir's observation of an absurd paradox characterising the situation of intellectual women: intellectual women are criticised by misogynists for renouncing the idea of femininity imposed by male-centred custom and fashion. In the meantime, intellectual women are admonished to stop primping themselves in order to be equal to men (Beauvoir, 2009: 740).

Obviously, Wang does not demonstrate awareness of such an absurd paradox; neither does Huang share her blissfulness. Upon waking up the next morning, Huang realises he slept with Wang while drunk. In a great fury, Huang shouts during Wang's singing class in the school playground that he "feel[s] like [she] raped [him]" (37'21'). He shoves her into the ground in front of all the students and staff and leaves Wang weeping, lying in the dust and dirt. Wang's relationship with Huang is thus made public as is his painting her nude. Since posing in the nude is considered promiscuous behaviour in the town, rumours about Wang's "infamous deed" soon spread widely and further her humiliation. Clad in her best opera costume, she attempts suicide by jumping from the pagoda, and in this way her first romance ends with trauma.

Huang Sibao's friend Zhou Yu is a more enthusiastic suitor. Zhou, a factory worker, comes to know Wang from a radio broadcast. He is struck by her beautiful voice and decides to learn vocal art from her. He lacks talent for singing but thinks himself a good match for Wang because he is financially stable and, upon Wang's recovery from her suicide attempt, he expresses his love with his material abundance. Wang, however, considers Zhou a poor match on an 
intellectual level. Wang is a consumer of high culture, as indicated by her love of classical music and opera, while Zhou consumes and prefers low culture. He continuously woos her with cassettes of the latest popular music. When Zhou asks for her hand, promising her a well-off life, Wang refuses and remains in her life as a school teacher, self-sufficient and single.

Wang's relationship with the ballerino Hu Jinquan is characterised by more mutual sympathy. $\mathrm{Hu}$ is ostracised by the local people because of his dancing career and homosexual disposition. Both $\mathrm{Hu}$ and Wang find each other misfits in the small town in which no one understands their artistic inclinations. Overburdened by the gossip and humiliation of local people, Hu asks for Wang's hand in marriage. To Hu, marriage will offer them both an escape from stigmatisation. Wang refuses Hu's proposal of a marriage of convenience. Here Wang's hunt for ideal love ends.

Ye, in The Postmodern Life of My Aunt, is no more successful than Wang in her pursuit of an ideal romance in urban Shanghai. Her romance with an urban underdog, Pan Zhichang, brings about a more pointedly embarrassing moment that also positions Ye as out-of-date. Ye comes across Pan practicing Peking opera in the park. Pan expresses his enthusiasm for both Peking opera and classical Chinese literature, and Ye is deeply fascinated by this shared intellectual taste and falls in love with him (figure5). 


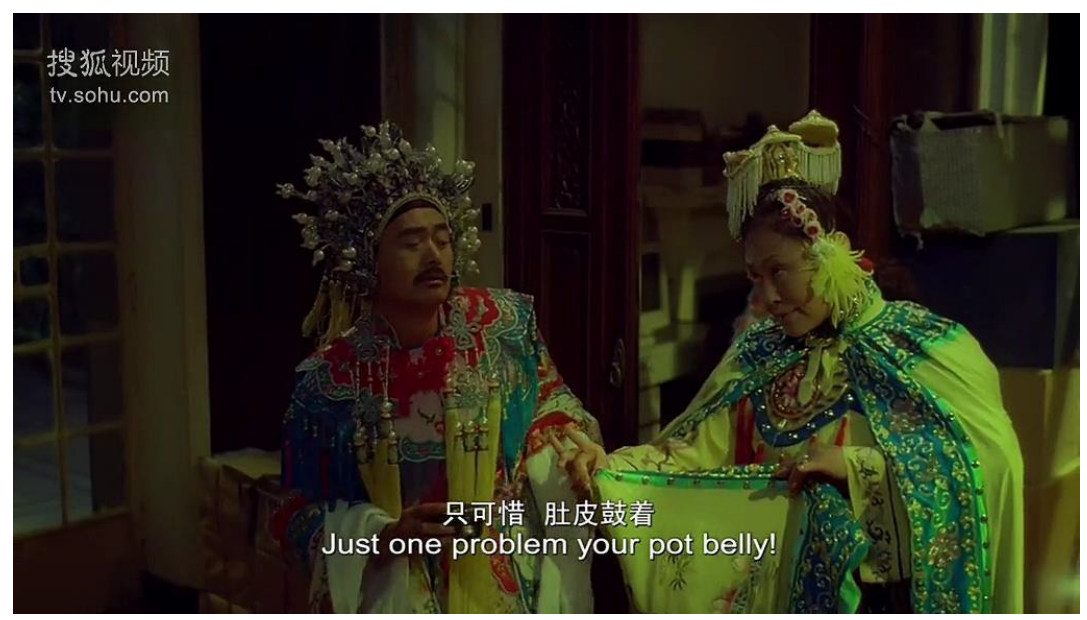

Figure 5: Ye and Pan having a ball performing Peking Opera in the costumes of the female roles (see Dailymotion, n.d.).

Upon his insistent demands, Ye relinquishes all her lifelong savings to Pan to invest in a cemetery. Pan runs off with her savings and leaves her penniless. Shocked, Ye faints on the stairs and breaks her leg. Lying in hospital, Ye sees her daughter for the first time after her years of escape. She is reprimanded by her daughter for her repudiation of the Confucian gender roles in a scene that can be read as a criticism by the patriarchal order of the intellectual woman's autonomy:

They called me unfilial, but are you a good mother? Did you ever do right by me? [...] You stayed with us when you needed our help. But as soon as you can move back to Shanghai, you got divorced just like that. Shanghai means more to you than Dad and I do (1h25'30'-1h25'53').

The travel between urban cities and the second-tier cities mark the motif 
of "escape" for both intellectual women in these films. Wang tries every means to escape from the town where she sees no hope for her dream. Her travelling is marked by her attempts in escaping from the dull and hopeless town to Beijing (figure 7). She travels frequently to Beijing in order to display her singing skills to the top-ranking National Opera Theatre. Time and time again she is rejected in the National Opera Theatre interviews. She tries by every possible means to stay, even exhausting her savings to buy a permanent residence in Beijing (the prerequisite for employment), and begging the theatre staff to offer her a position as an usher. Having undergone all these frustrations and failures, Wang goes back to her town, masquerading as a well-educated woman and famous local opera singer, thus setting herself in stark contrast to her subservient ways in Beijing. She tells the local people that her talent is greatly appreciated by the National Opera Theatre authorities who have invited her to work in Beijing as soon as possible (figure 6).

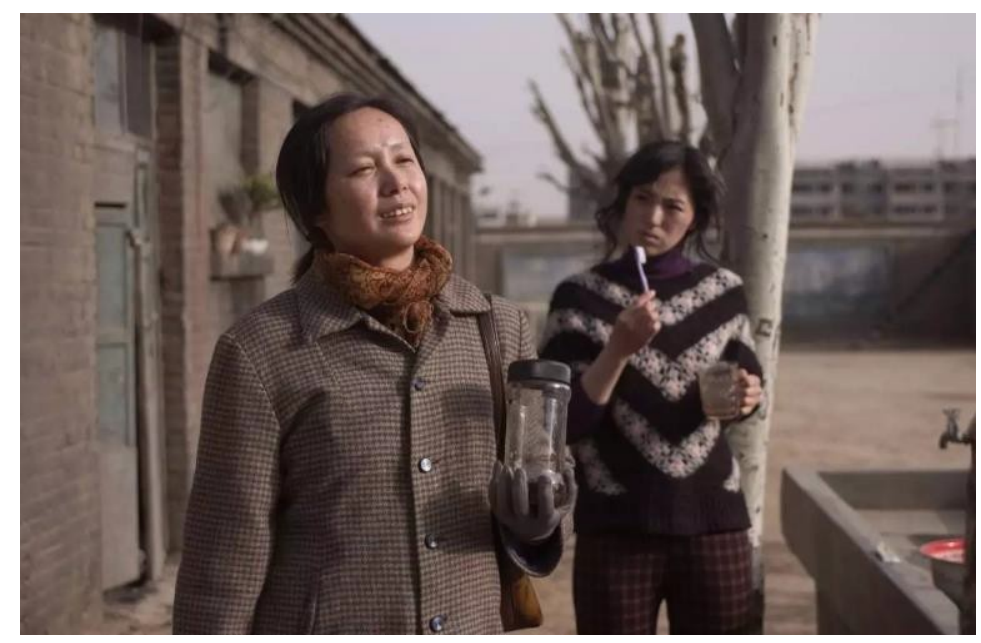

Figure 6: Wang returns to her town and proudly tells her neighbour about the hospitality and respect she received from the National Opera Theatre (see KKNews, 2017b). 
In so doing, Wang falsely elevates herself to the pinnacle of the art world, enjoying the admiration of less-educated locals who worship her not only for her voice but also her connections to the outside world, the metropolis Beijing. Pierre Bourdieu might describe her as affirming her claim to a legitimate superiority over other locals by not just her aesthetic disposition, "one dimension of a distant, self-assured relation to the world and to others" (Bourdieu, 1996: 56), but also her educational and social capital, which entitle her to an "aristocracy of culture", which is also shared, as indicated before by Ye Rutang in The Postmodern Life of MyAunt.

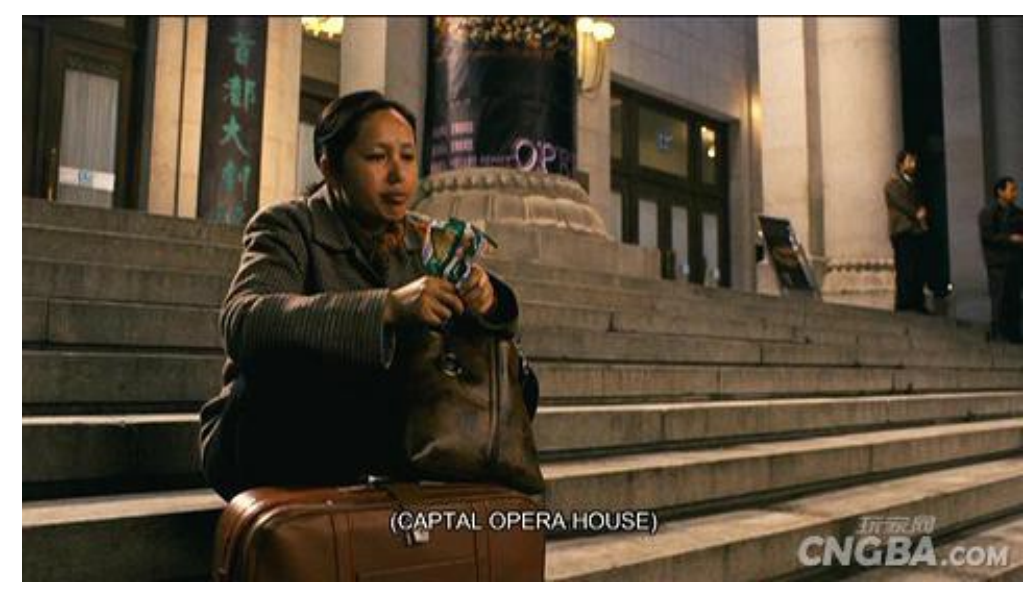

Figure 7: Wang waits anxiously outside the Capital Opera House until the opera Tosca begins. In this way, she is able to buy discount tickets from the scalpers. Wang's consumption behaviour here may remind us of Bourdieu's "ascetic aristocratism", 5 an expression of her aristocracy of culture (see Duowan.com, 2008).

5 "The ascetic aristocratism of the teachers (and public-sector executives), who are systematically oriented towards the least expensive and most austere leisure activities and towards serious and even somewhat severe cultural practices." See Bourdieu (1996: 286). 
In The Postmodern Life of My Aunt, Ye escapes from the industrial city of Anshan and settles in Shanghai without bringing her husband and daughter along. For years, Ye enjoyed her independence as a financially sustainable intellectual woman of refined taste. Having experienced disastrous financial loss and eventual recovery from her injury, Ye returns to Anshan and lives with her husband again. In the latter half of the film, Ye's escape is portrayed as repudiating the identity and lifestyle of an intellectual woman. The camera is set in the dusty and shabby apartment of a factory worker where Ye no longer appears as a vigorous and neatly-dressed intellectual woman. In this scene, Ye is busy mopping the floor while her husband sits on the sofa, brushing his teeth, focusing on the noisy TV comedy and spitting on the floor where Ye has just mopped. Seeing that, Ye cleans the floor again wordlessly. Ye is thus performing a dystopian version of the Confucian woman via her subservience to the husband.

In most scenes set in Anshan, Ye remains silent and appears to be doing housework. But the final scene is set in the flea market where Ye sells shoes with her husband. There, Ye turns on the radio, which plays the same excerpt of Peking opera she used to practice in Shanghai (figure 8), and is lost in her meditation. This final scene is open to several readings: Is the music reminding her of her identity as an intellectual woman? Is she satisfied with her choice to abandon that life? Is she satisfied with either of her attempts at escape? Does being a non-intellectual-woman mean less autonomy in demonstrating her subjectivity? 


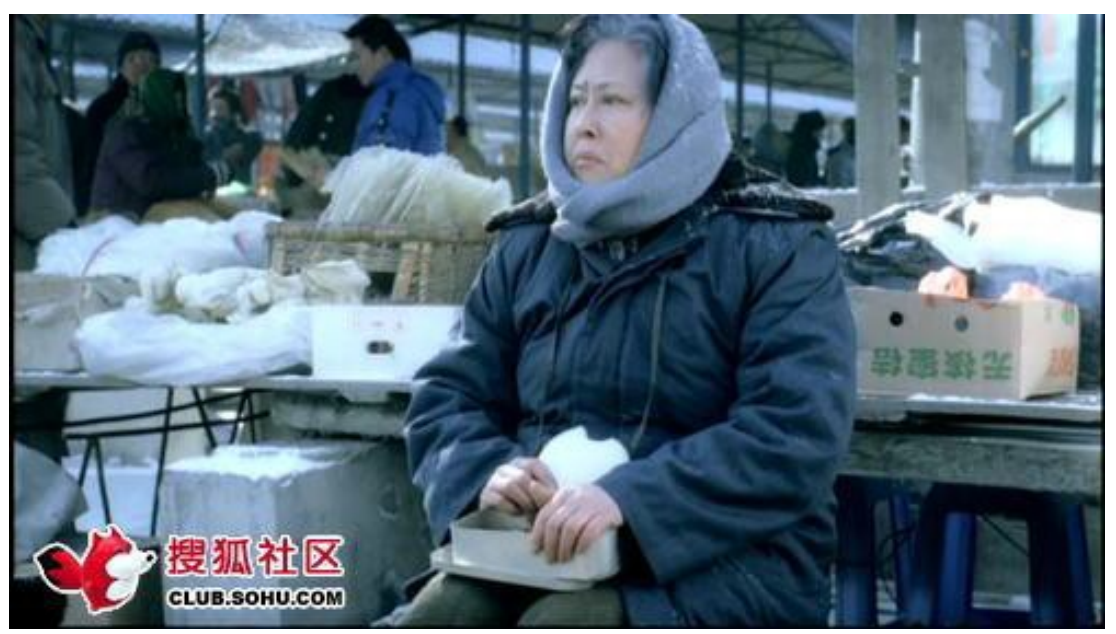

Figure 8: The ending scene in The Postmodern Life of My Aunt. In the chilling winter morning, Ye is eating steamed buns and selling shoes in the flea market. The very Peking Opera song she used to sing in Shanghai with Pan is played from a radio somewhere nearby (see Sohu.com, 2007).

In And the Spring Comes, having undergone a series of emotional and spiritual traumas, Wang gives up hope on marriage and love, and is also estranged from the power that comes with her fame as a lyric soprano who is about to move to Beijing. Wang escapes from the town and moves to a more remote area, giving up her singing career and becoming a butcher. Towards the end of the film, a close-up shot features Wang and her adopted daughter in Tiananmen Square in Beijing. They speak with a northern accent rather than the Beijing dialect, asserting their identities as outsiders of the city which highlights Wang's periphery vis-a-vis the centre of power (figure 9). 


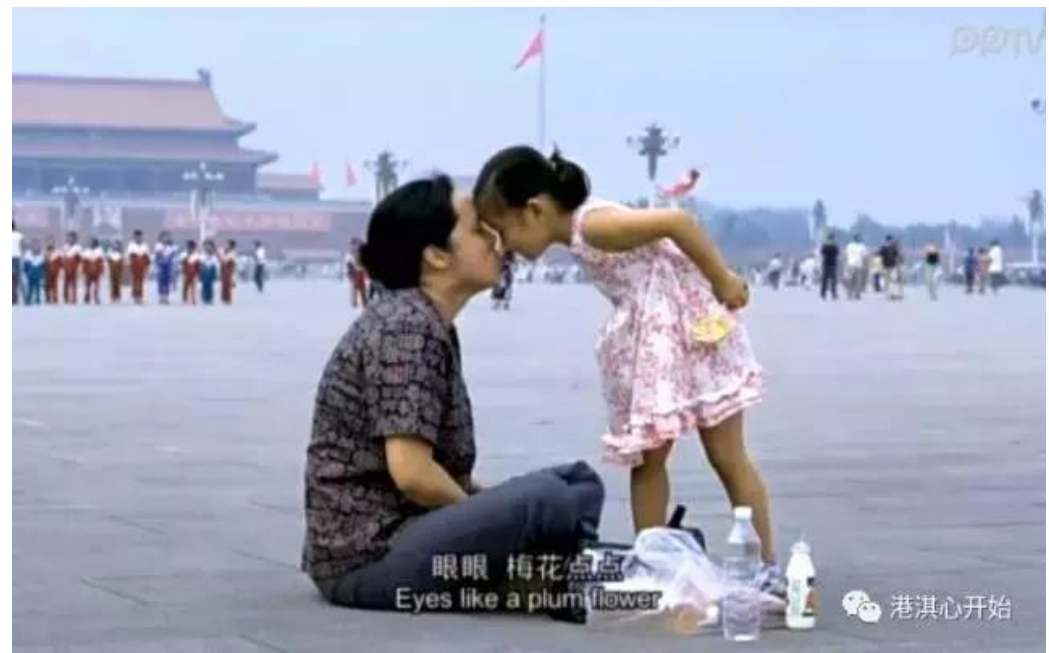

Figure 9: Wang and her stepdaughter chant rhymes in Tiananmen Square (see KKNews, 2018).

Wang's imagination soon merges with this ending scene. In the coda, Wang envisions herself singing Vissi D'arte from Tosca in the National Opera Theatre. The film score plays the latter half of the aria, which laments the woman's tragic fate, thus strengthening the tragic tone of the film and the tragic fate of Wang Cailing. ${ }^{6}$

Both And the Spring Comes and the Postmodern Life of My Aunt represent post-Mao intellectual women's pathetic/tragic and even comical struggles. Although both women are staged as idealistic pursuers of true love with artistic temperaments and a taste for a high-class lifestyle, their struggles reveal a less than idealistic negotiation with the possibilities of being intellectual women. At

\footnotetext{
${ }^{6}$ The English translation of lyrics is provided as follows: "Why, why God? In this hour of grief, do You repay me this way? In tribute to Your beautiful creation, I gave jewels to the Madonna's mantle, and offers my songs to the stars and Heaven. Why, why God, in this hour of grief, do You repay me this way?" (Fisher, 2004: 297).
} 
the conclusion of both films, Wang and Ye fail to maintain their roles as intellectual women and to uphold their identities as intellectual women. Their life trajectories, marked by practices of estrangement and escape, finally turn themselves into the particular "sixth finger(s)" who seem to be less necessary in a rapidly changing society dominated by a conjunction of Confucianism, socialism, post-socialism and neoliberalvalues.

The less than idealistic negotiations appear not only in the cinematic representations of middle-aged intellectual women, but also in the lived experience of young intellectual women in the early twenty-first century, which will be presented in the next section.

Intellectual Women, Prejudicial Labels and the Fight-Back Response in the Post-2000s: Cyberspace, Propaganda, and Other Popular Cultural Products

While modern Chinese feminist forerunners in the early twentieth century often celebrated their celibacy as a sign of emancipation and independence from the patriarchal system, celibacy among educated women is seen as a "problem", or as bringing "trouble", a century later. In the first decade of the twenty-first century, the major concern for young intellectual women captured in popular culture is still the destiny of love and marriage. Cases of female holders of, or candidates for, doctoral degrees, as well as older single women, figure prominently in media discourse in the first decade of the twenty-first century, in which the estrangement and escape of Chinese intellectual women are viewed as problems for Chinese society.

This public concern over women with high educational qualifications, especially those holding or studying for a doctoral degree, poses the question of 
their proper location in the cultural order. As public female images, they are vilified because they are seen to abandon or reject the importance of heterosexual romance, love and marriage. This, in turn, leads to embarrassing moments for a new generation of intellectual women.

In the early 2000s, a popular quote appeared in wide circulation in Chinese cyberspace, which read: "There are three types of people in the world: men, women and female doctoral degree students/holders" (Anonymous, 2011). This evolved and blurred into the further claim that "female doctoral students/holders are equivalent to the Destructive Nun (Miejue Shitai 灭绝师 太)" (Fu, 2007). ${ }^{7} \quad$ They are "UFO (ugly, foolish and old)" (Wang, 2012). These internet and social media phenomena underscore the discrimination directed at female doctoral students/holders. The Destructive Nun is an evil female character in a martial arts novel by Louis Cha (also known by his pen name Jin Yong 金庸). Another insult seen in Chinese online discourse which is used to characterise educated women includes not only female doctoral students/holders, but also those who hold or undertake lower academic degrees:

Female undergraduates can be called Little Dragon Daughter (Xiao Longnü 小龙女). Female postgraduates (those who undertake master's degree) are Li Mochou (李莫愁). Female doctoral students/holders are therefore entitled to be called "the Destructive Nun" (Ye, 2010). ${ }^{8}$

\footnotetext{
${ }^{7}$ Destructive Nun is a Buddhist nun with superb martial art talents, who is known for her wrath in Jin Yong's novel The Return of the Condor Heroes. The novel was serialised in Ming Bao Daily News beginning on May 20, 1959.

${ }^{8}$ Little Dragon Daughter is the protagonist in Jin Yong's The Return of the Condor Heroes, and is known for her chastity and immortal youth and beauty, whereas Li Mochou, somewhat older, is the villainess in the novel, and is noted for her beauty and viciousness. The Destructive Nun, as noted above, is old and completely lacking charm, inspiring only fear.
} 
The publicly perceived dilemma of female doctoral students/holders is also well illustrated in the meme "When Man Meets Woman. Woops" (当男人遇到女人， Figure 10), virally popular on Chinese websites at the end of 2011 (Gongfu, 2012).

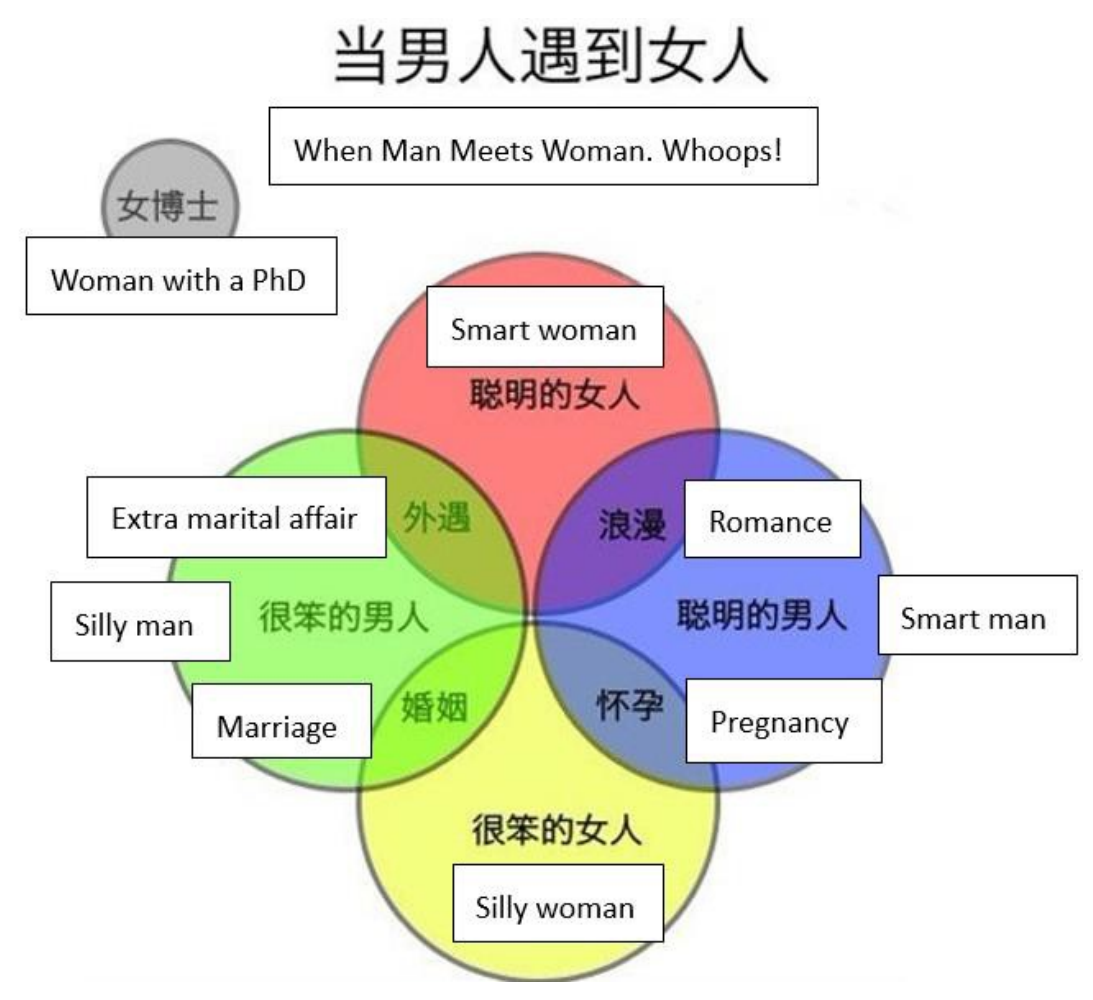

Figure 10: "When A Man Encounters a Woman, Woops" (see Liu, 2011).

The image depicts a series of possibilities for heterosexual relationships and encounters, and the female $\mathrm{PhD}$ in grey remains estranged from them all. Both the Destructive Nun phenomenon, and the meme depicted above, convey that the higher a degree the woman achieves, the less attractive and charming she becomes. These slogans and memes generated waves of heated discussion on online discussion forums, blogs and leading bulletin board systems, in which 
there was a consensus that "female doctoral students/holders lack femininity" (nü boshi mei you nüren wei 女博士没有女人味) (Anonymous, 2010). This stereotypical configuration bears similarity to my definition of "estrangement", that is, becoming an intellectual woman (by attaining a high academic degree) sometimes means the rejection of patriarchal norms of femininity. In such a configuration, women assume the place of the castrated Other. Thus, they are often perceived in an antagonistic way as unnatural manly women who are, as Christopher Prochasson noted, "quite the opposite of a mother or wife, as the meaning behind the facts changes, she becomes a man, but an incomplete, impotent and vicious one" (Prochasson, 2001: 57, cited in Long, 2013: 14, 112).

The globalisation of elite single professional womanhood has emerged as a new global phenomenon in the twenty-first century (Berg-Cross et al., 2004: 34). In recent decades in China, much public attention has been drawn to the heterosexual relationships and marital status of women with educational achievements in match-making TV reality shows, for example in the especially controversial show If You are the One (Feicheng wurao 非诚勿扰), which has aired on Jiangsu Satellite TV since 2010. The show consistently fails to find a match for its female participants who have or are studying for a doctorate. Sun Lin's observation of the stigmatisation of female doctoral holders in the show is helpful in understanding the hostility and hostile discourse against intellectual women in public media. Sun takes these female participants as transgressors (jianyuezhe 僭越者), who do not abide by the normative gender ideal of being a submissive mother and wife (Sun, cited in Wang \& Lü, 2016: 284-5).

The transgressive subjectivity of intellectual women here again fits well with my description of intellectual women as actors of estrangement. As Sun observes, female doctoral-degree holders are often portrayed by the public as exaggerated stereotypes suffering from problems with employment, psychology, 
love and marriage. Upsetting the patriarchal order, these women are thus punished. As "kindly" suggested by propaganda media outlets such as Liberation Daily (Jiefang ribao 解放日报), aiming to “vindicate female doctoral holders", these problems are resolvable only when high-achieving women demonstrate their equal capability in managing household affairs (Sun, 2016: 285, 279). Clearly, these Chinese reality shows and propaganda media aim to preserve patriarchal gender constructions and perpetuate the stereotypical gender roles of women via their "kind suggestions".

Similarly unflattering and prejudicial portrayals are also highlighted in Hannah Feldshuh's study of popular TV shows and romance TV series, including the aforementioned If You are the One, Let's Get Married (Zanmen jiehun ba 咱 们结婚吧, dir. Liu Jiang, 2013) and iPartment (Aiqing gongyu 爱情公寓, dir. Wei Zheng, 2011). Feldshuh's research demonstrates that the sexist mediaconstructed myth of shengnü (剩女， meaning leftover women), in which intellectual women are depicted as strange and abnormal (Feldshuh, 2018: 42), "being not easy to cope with", "having little knowledge about romance" and "being too picky in choosing partners" (Ka, 2017). ${ }^{9}$ Both the "third sex" and shengnü discourses contain "semantic derogation" (Feldshuh, 2018: 42) against well-educated women. This can also be understood as linguistic violence (Jiang \& Niu, 2008: 46-7) whereby the media accentuate the stereotypical portrayals of intellectual women who are pedantic, lacking social skills and sexually unattractive. In so doing, discrimination against single women, especially the educated ones among them, is exacerbated (Gong, Guo \& Jiang, 2018: 5). Therefore, the mass media legitimises the othering of intellectual women from the social order established by the patriarchal ideology. The othering of

\footnotetext{
9 These are netizens' comments made about Zhang Xiaochen, a female contestant in If You Are the One in 2012. Zhang was 30 at the time. She held a PhD from The London School of Economics. Zhang claimed in her personal statement that it was much easier for her to be offered a degree at Oxford University than to get a boyfriend.
} 
intellectual women is well reflected in the case of If You Are the One contestant Xu Yali in 2015. Xu introduced herself as an associate professor as well as a PhD holder who admitted to concealing her degree from others. Such abnegation reflects the dilemma: educational advancement is a desirable credential for the career market but undesirable for the marriage market.

The "leftover women" phenomenon caused notable public concern in the popular media around 2006, and "shengnü" was listed as one of the 171 new words of 2007 by the Ministry of Education in China (The State Language and Writing Commission, 2007). "Leftover women" refers to single women twentyfive years or older who have advanced degrees, a successful career, a decent income and a bank account. However, the connotation of the pejorative term is that these leftover women experience a problem linked to their higher standards for a husband. Their education, social status, and income threatened Chinese men from pursuing them, resulting in their leftover-ness. In fact, "leftover women" is a word play on "saintly women" in Chinese, which indicates the superiority as well as estrangement thought to characterise these intellectual women. The older the leftover women becomes, the less possible, it is imagined, that she will get married. In the same year, state media outlet Xinhua News Agency published the definition of "leftover women" provided by the All China Women's Federation (ACWF). According to this official definition, single women over the age 27 are categorised as "leftover" (Fincher, 2014: 3; see also To, 2015: 1). It is necessary to incorporate here Leta Hong Fincher's pioneering research on, and substantial coverage of, China's state media campaign on the leftover women. An official statement from the ACWF website published in 2011 is worth noting here:

Pretty girls don't need a lot of education to marry into a rich and powerful family, but girls with an average or ugly 
appearance will find it difficult. These kinds of girls hope to further their education in order to increase their competitiveness. The tragedy is, they don't realize that as women age, they are worth less and less, so by the time they get their M.A. or Ph.D., they are already old, like yellowed pearls (cited in Fincher, 2014: 3)

Ironically, the statement was published after International Women's Day, a day commemorating women's liberation and gender equality. The official depreciation against single women of "marriageable age" as well as the insulting anti-intellectualism is made clear.

In 2012, Jiayuan.com (Shiji jia yuan wang 世纪佳缘网), the biggest online dating website in mainland China, published "Confession from the Leftover Women" (Shengnü zibai shu剩女自白书), a survey conducted on the "leftover women" phenomenon with 88,516 participants (Feng, 2012). The survey gives a detailed description of "leftover women". Most of these unmarried women were born in the 1970s and 1980s, and are well-educated, economicallystable, charming and intelligent. They are also characterised by what is frequently described by the Chinese media as having "high taste" in choosing their partners/husbands. These statistics indicate that most of those who identify themselves as "leftover women" are noted for their higher incomes, higher education, and higher social status. Their elite situation is also captured by other

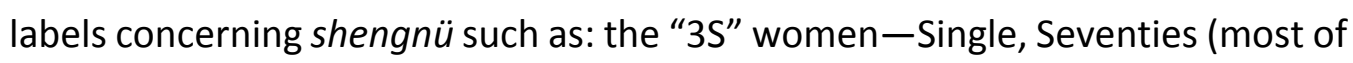
them were born in the 1970s), and Stuck; "High Education, High [Professional] Position, High Income"; and "Great Sage Equal to Heaven" (Qitian Dasheng 齐 天大圣), for leftover women over 35 (Fincher, 2014: 27-8); as well as "Whitecollar, Backbone, Elite" where the first character of each of the three words compose Bai Gu Jing (白骨精, the White Bone Demon), the name of the female 
demon in the classical novel Journey to the West.

In other words, the more education a woman receives, and the higher the income bracket she attains, the more unwelcome she is to the prospective suitors, and therefore, the more difficult it is for her to get married. According to Gong Haiyan, CEO of Jiayuan.com, the elevation of women's education levels and financial capacity in recent years allows them more spiritual and material independence (Weili, 2009). This can be taken as a sign of estrangement, when these well-educated, high-salaried single women live a different lifestyle which gives them more freedom and independence but detaches them from the socially valued ideals of femininity. Thus, being estranged, they escape from the patriarchal gender construction of women as wife or mother. Their spiritual and material independence also results in "more idealistic expectations" concerning love, as love is not indispensable to them. It is believed by Feng Zhijun that most leftover women choose to maintain their celibacy (Feng, 2012).

Responding to these prejudicial labels against intellectual women was what I would call the fight-back response in post-2000s Chinese popular contexts. Often featured in a positive manner, the fight-back response manifests the lifestyles and outlook on relationships of the Chinese "être particulières". "Song of an Elder Artistic Woman", a ballad by Shao Yibei (邵夷贝), is replete with the innuendo of this fight-back (seasoned with ridicule) against the sexist shengnü discourse. The song is based on the singer's own experience. Then in her early twenties, this 1980s-born graduate of Media and Communication at Peking University was constantly bothered by her mother's endless complaints about her celibacy ( $\mathrm{Ma}, 2012:$ 96). In a Chinese cultural context, daling (大龄, over-age or mature-age) followed by the word qingnian (青年, youth) is used exclusively for those who have already reached marital age but are still single, while wenyi 
(文艺) is defined by connoisseurship in literature and art. ${ }^{10}$

The video of Shao singing the song in February of 2009 spread quickly in Chinese cyberspace. The protagonist, "Miss Wang” bears Shao's own self-image (Ma, 2012: 96). Miss Wang becomes a headache to her parents and friends because she has not found a suitable husband-to-be. They offer her two suggestions: she can either date male artists who share her interests, or economically stable men who can offer financial support for her artistic endeavours. However, the song goes on to represent male artists as selfabsorbed philanderers. Marrying a rich man could be the wise or pragmatic decision, but Wang does not fit the gender stereotype favoured by the rich, who prefer traditional housewives with excellent culinary skills. Women who cannot fulfil this traditional gender ideal would end up being only their mistresses, still considered despicable in both Maoist and post-Mao discourses and contexts (Evans, 1997: 207). The song concludes with a comment on Wang's culinary capabilities, highlighting that she has some capacity with domestic chores; she can stir fry tomato with scrambled eggs, one of the most ordinary Chinese dishes that requires only elementary cooking skills.

The song brims with light-heartedness. The self-deprecatory humour is well expressed by its lyrics and solo guitar accompaniment. Shao is an ardent enthusiast of folk-rock, and it is evident that this song insinuates, in a subtle way, the ethos of rock: the resistance against or attempts of subversion of the dominant ideology. Therefore, it can be assumed that she has inherited Chinese rock-n-roll veterans' understanding of rock music as a form of "authentic selfexpression and emotional release in the face of oppression" (cited in Murray, 2016: 5; see also Jones, 1992: 91). In the case of "Song of an Elder Artistic

\footnotetext{
${ }^{10}$ Wang Cailing in And the Spring Comes is hailed as a paradigm of artistic youth by the Chinese media. See Xiari Qiangwei (2015).
} 
Woman", Shao challenges the dominant narrative in contemporary China that women should be married off in the so-called "prime age" for child-bearing and be skilful in the art of household management. Her resistance is expressed in a subtle and cynical self-deprecating way, which showcases her indifference towards the admonishment of her mother, and the prevalent public attitudes against unmarried older women.

Apart from "Song of an Elder Artistic Woman", another fight-back act became evident in the emergence of the "blossoming women" (shengnü 盛女) phenomenon. "Blossoming women" is a Chinese wordplay on "leftover women", which also gives rise to a positive self-identity of being the particulières. This wordplay reflects especially intellectual women's changing views towards family and marriage in the early twenty-first century. Similar to Shao Yibei and her alter-ego Miss Wang, leftover women have to "brave the tide of political, cultural and parental waves pushing her towards marriage" (Lake, 2012). An interesting indication in the Jiayuan.com survey is that $48 \%$ of the "leftover women" indicate that they are actually enjoying life as single women (Shenzhen Daily, 2012). At least some of these women proudly name themselves "blossoming women" in cheerful recognition of their identity as single women (Shenzhen Daily, 2012). The blossoming shengnü thus becomes triumphant title for many independent single women who battle against male-dominated society.

Research on the emergence of the "leftover women" phenomenon has proliferated in recent years. Attention is drawn especially in the areas of Chinese women's socio-economic status against the backdrop of China's booming real estate business (Fincher, 2015), the well-educated leftover women's "emergent adulthood" resulting in the negotiation of womanhood and marriage norms (Gaetano, 2014: 124), as well as their social mobility (Gaetano, 2015: 18). ${ }^{11}$ This

\footnotetext{
11 Research also includes ethnographic studies of female migrant workers.
} 
research suggests the rising autonomy and independence of the Chinese leftover women, many of whom, if not all, can be defined as intellectual women on the basis of their education level and career.

Intellectual women's celibacy, one of the telling signs of autonomy and independence, is often criticised by state media as evidence of their being "too picky" (Fincher, 2014: 20). ${ }^{12}$ However, the criticism did not stop the celebration of "blossoming women" on popular media which takes the shape of TV series and films themed with the lives of well-educated and single women in urban China. These may include TV series such as The Golden Age of the Blossoming Woman (Shengnü de huangjin shidai 盛女的黄金时代, dir. Lan Zhiwei, 2011)， Ode to Joy (Huanle song 欢乐颂, dir. Kong Sheng, 2016) and its second season (2017), The First Half of My Life (Wo de qianbansheng 我的前半生, dir. Shen Yan, 2017), Women in Beijing (Beijing nüzi tujian 北京女子图鉴, dir. Li Zhi, 2018) and the film I Do (Wo yuanyi 我愿意, dir. Sun Zhou, 2012), to name a few. These

popular cultural products offer new interpretations of Chinese women, especially the well-educated middle-class among them, and of how they manifest various partner choice strategies. Key female characters in these popular products stun the audience by their educational background, professional success as well as sense of fashion and taste. Among them, the successful professional woman Tang Jing in The First Half of My Life, and An Di in Ode to Joy, a CFO who used to study and work in New York, are the paragons.

However, apart from these women's shining credentials, these stories are also punctuated with the female protagonists' romantic relationships with men. In these stories, the blossoming women could often be seen negotiating with

12 According to Sandy To's qualitative research conducted among 50 unmarried professional women in major cities in China, male superior norms also account for discrimination against professional women in the marriage market. In this sense, accomplished women are criticised as "being too tough". See To (2015: 32-54). 
gender role perceptions and social constraints in their relationships. One may find Sandy To's research on the late marriage phenomenon among welleducated Chinese professional women relevant in viewing these emotional entanglements (even though they are fabricated). Based on her interviewees' marriage views, economic values, gender role perceptions, patriarchal and filial constraints, as well as partner choice strategy, To categorises Chinese leftover women into traditionalist, maximiser, satisfier and innovator (To, 2015:161). ${ }^{13}$

Indeed, the research suggests that Chinese leftover women are not unanimously estranged from traditional marriage views. In the abovementioned cultural products, the blossoming women, however, all have marriage outlooks and partner choices that fit in the category of either satisfiers or innovators. Both satisfiers and innovators uphold democratic views and egalitarianism in relationships. For them, male partners' patriarchal control over their work-life styles are highly undesirable (To, 2015: 161). For the satisfiers, marriage is indispensable. In The Golden Age of the Blossoming Woman, Liang Shuang and Ou Lele find their Mr Right by the end of their love adventures. The TV series portrays the ideal male partner/husband as someone who holds egalitarian views and respects her work-life choices. Unlike the satisfiers, the innovators, like Chen Ke in Women in Beijing and Tang Jing in The First Half of My Life, do not consider marriage as their ultimate life goal. They are prone to aspiring towards non-traditional relationships, in which they can benefit from more autonomy and satisfaction (To, 2015: 161), and achieve further career success.

\footnotetext{
${ }^{13}$ According to To, both traditionalists and maximisers consider marriage as their ultimate life goal, prefer slightly asymmetrical household roles with partners, and want to have partners of similar socio-economic background. Compared to the traditionalists, the maximisers have concrete partner choice strategies including: looking for "open-minded" Westerners and men who are much more accomplished in their careers. See To (2015: 161).
} 
It is worth noting To's optimism towards the label "leftover women", which she took as a compliment (Cheng, 2013). The optimism is also shared in these stories of blossoming women. The female characters, albeit negotiating with gender constraints and marriage norms in post-Mao China, lead a confident and self-fulfilling lifestyle regardless of their relationship status (To, 2015: 27), be it single, divorced, in love or married. These stories conclude with an optimistic tone. As discussed earlier, Aunt Ye in The Postmodern Life of My Aunt and Wang Cailing in And the Spring Comes give up their ideal work-life style as their stories end. Unlike them, these blossoming female characters demonstrate personal satisfaction in their work-life style. They have the autonomy of escaping from various gender, social and economic constraints. Their autonomy enables these female characters to become particulières. As the stories conclude, these female characters remain comfortably single and professionally successful (the cases of Tang Jing, Chen Ke, and Fan Shengmei in Ode to Joy II), or embark on a new round of ideal-man-seeking adventures (the case of Tang Weiwei in I Do). In this way, these "blossoming women" present diversified versions and possibilities for female identities which may be a reminder of how Irigaray understands women's sexuality, imaginary and language, as "not one" (1985: 23), as is also reflected in To's subtle categorisation. Again, this not-oneness could be regarded as another a sign of being "particulière". It can be argued that the fight-back response gives rise to positive cultural representations of Chinese intellectual women who were prejudicially labelled in cyberspace and state media in the previous decade.

\section{Epilogue}

The Chinese intellectual woman's future is clearly at stake as demonstrated by the labelling and the pathetic comedy of Wang Cailing and Aunt Ye that is 
discussed in this article. The labelling perpetuates the prevalent discrimination and animosity against intellectual women. The films The Postmodern Life of My Aunt and And the Spring Comes represent intellectual women's fruitless struggles against an environment that is unfriendly to their personal satisfaction as well as career and life pursuit. The two cinematic works and the prejudicial labelling reveal the situation of contemporary Chinese intellectual women. This situation could hardly be described as satisfactory.

As indicated by "Song of An Elder Artistic Woman" and the "blossoming women" phenomenon, the fight-back response in popular cultural products constructs positive and optimistic images of the Chinese intellectual women, i.e., the confident "particulières", while promoting alternative gender values for Chinese women in the twenty-first century.

However, the fight-back response still appears more feasible in media representations than in reality. The "Online Survey on Gender Issues in Mainland Chinese Academic Institutes" (Guonei xueshu jigou xingbie wenti diaocha 国内 学术机构性别问题调查) may provide supplementary evidence addressing the existing discrimination against intellectual women in contemporary China. Published in 2015, the survey received 1,600 responses online from students and academics in more than 40 Chinese academic institutions. The findings suggested that discrimination against women had driven a fair number of female scholars away from furthering their academic undertakings. Compared to their male colleagues, female scholars were more susceptible to discrimination in both their career and life. Academic supervisors and directors, it was revealed, are the major source of discrimination. The report also discloses a dire statistic that women occupy only a small number of senior academic positions, accounting for only $20 \%$, according to the report (Luo, 2016; see also Wang et al., 2015). 
Another figure published by the Ministry of Education in 2016 suggests an exacerbation of this gender imbalance: the number of female PhD was 132,132; this accounted for $38.63 \%$ of the overall number of PhD students in China in 2016 (Zhang \& Li, 2018; Shen, 2018). One may argue that gender discrimination against female scholars is the catalyst of intellectual women's escape. Gender discrimination deters intellectual women from pursuing their careers and fulfilling their ambitions. In 1907, Otto Weininger published his highly essentialised research the character of women, maintaining women's deficiency in areas such as logic, memory and consciousness (Tuana, 1983: 65). More than a century later, the misogynist ghost of Weininger is haunting the other end of the Eurasian continent, manifesting itself through the highly-educated male knowledge elites in China.

Addressing the issues of Chinese intellectual women in the early twentyfirst century, the two motifs of estrangement and escape reflect how Chinese intellectual women are represented and rendered in the Chinese popular cultural context with frequent animosity, prejudice and discrimination. It would be simplistic to say that estrangement and escape are universal characteristics of the Chinese intellectual women and that they will always cling to such trajectories. Instead, this article indicates that estrangement and escape mirror how Chinese intellectual women contest normative gender politics while constructing their subjectivity and gender roles within a rapidly changing society, as indicated in my analysis of The Postmodern Life of My Aunt, And the Spring Comes, "Song of An Elder Artistic Woman" as well the "blossoming women" phenomenon.

Chinese intellectual women are still paving their way along what promises to be a long march, struggling with this dilemma and armoured with their estrangement and escape. Echoing the global campaigns against sexism and 
misogyny, the Chinese \#Metoo movement has gained momentum since 2017. As the movement escalates, female consciousness, long-heralded by Chinese "être particulières", continues to be coupled with a spirit of rebelliousness and fighting.

\section{References}

Alchetron (2018), "And the Spring Comes", Alchetron, available at: https://alchetron.com/And-the-Spring-Comes (accessed 22.01.2019).

Anonymous (2010), "Nü boshi zhaobudao duixiang de zhenzheng yuanyin" (Why female PhDs can't find a husband), Baidu, available at: http://tieba.baidu.com/p/468999010 (accessed 28.03.2012).

Anonymous (2011), "Shijieshang you sanzhong ren: nanren, nüren, nüboshi" (There are three types of people in the world: men, women and woman PhDs), Renren.com, available at:http://blog.renren.com/share/220873133 /4892397405/1 (accessed 18.01.2011).

Baike (2015), "Yima de houxiandai shenghuo" (The Postmodern Life of My Aunt), Baike.com, available at: http://www.baike.com/wiki/\%E3\%80\%8A\% E5\%A7\%A8\%E5\%A6\%88\%E7\%9A\%84\%E5\%90\%8E\%E7\%8E\%B0\%E4\%BB\%A 3\%E7\%94\%9F\%E6\%B4\%BB\%E3\%80\%8B?prd=so_1_doc (accessed 22. 01.2019).

Bailey, Paul (2012), Women and Gender in Twentieth Century China, New York: Palgrave MacMillan.

Barlow, Tani (1991), "Zhishifenzi [Chinese Intellectuals] and Power", Dialectical Anthropology 16(3/4): 209-332.

Beauvoir, Simone de (2009), The Second Sex, trans. by Constance Borde and Sheila Malovany-Chevallier, London: Jonathan Cape.

Béja, Jean-Philippe (2003), "The Role of Intellectuals in the Reform Process", 
Contemporary Chinese Thought 34(4): 8-26.

Berg-Cross, Linda, Anne-Marie Scholz, JoAnne Long, Ewa Grzeszcyk and Anjali Roy (2004), "Single Professional Women: A Global Phenomenon Challenges and Opportunities", Journal of International Women's Studies 5(5): 34-59.

Bordo, Susan (1993), Unbearable Weight: Feminism, Western Culture and the Body, Berkley and Los Angeles: University of California Press.

Bourdieu, Pierre (1969), "Intellectual Field and Creative Project" trans. by Sian France, Social Science Information 8(2): 89-119.

- - (1996), Distinction: A Social Critique of the Judgement of Taste, Abingdon: Routledge.

Cao Guangfu (2011), “Nü boshi de hunyin wenti bei yaomohua?” (Are the marriage issues of women PhDs being vilified?), Sciencenet, available at: http://blog.sciencenet.cn/home.php?mod=space \&uid=40247\&do=blog\&i $\mathrm{d}=472825$ (accessed 19.08.2011).

Cheek, Timothy (2015), The Intellectual in Modern Chinese History, Cambridge: Cambridge University Press.

Chekov, Anton (2014), Three Sisters, Indianapolis and Cambridge: Hackett Publishing Company.

Chen, Ya-chen (2011), The Many Dimensions of Chinese Feminism, New York: Palgrave MacMillan.

Cheng, Tinny (2013), “Gangda shengnü baogao xueshu jiaodu jie tuosheng jiasuo" (Leftover Women Report from The University of Hong Kong reveals factors of remaining single), Hong Kong Economic Journal, available at: http://lj.hkej.com/lj2017/artculture/article/id/57616 (accessed 05.01. 2019).

Dailymotion (n.d.), “Dianying 'Yima de houxiandai shenghuo' zhuyan Siqin Guwa Zhou Runfa Zhao Wei Lu Yan Shi Ke part 2" (The director of the film 'The Postmodern Life of My Aunt' Siqin Guwa Zhou Runfa Zhao Wei Lu Yan Shi Ke part 2), Dailymotion, available at: https://www.dailymotion.com/vid 
eo/x2k6my4 (accessed 22.01.2019).

De Kloet, Jeroen (2010), China with a Cut: Globalisation, Urban Youth and Popular Music, Amsterdam: Amsterdam University Press.

Duowan.com (2008), "[PMP] 07 Luoma dianyingjie zui jia nü yanyuan jiang 'Lichun'" ([PMP] 07 The Best actress award at the Rome Film Festival goes to 'And the Spring Comes'), Duowan.com, available at: http://psp.duowan.com/0804/73328111457.html (accessed 22.01.2019).

Evans, Harriet (1997), Women and Sexuality in China: Female Sexuality and Gender Since 1949, New York: Continuum.

Feldshuh, Hannah (2018), "Gender, Media, and Myth-Making: Constructing China's Leftover Women", Asian Journal of Communication 28(1): 38-54.

Feng, Jiayun (2017), “'Women Don't Belong in Academia'-Male ProfessorChina's Latest Society and Culture News" , SupChina, available at: http://supchina.com/2017/10/23/women-dont-belong-academia-male professor-chinas-latest-society-culture-news/ (accessed 27.10.2017).

Feng, Zhijun (2012), "Shiji jiayuan fabu nannü hunlian guannian xilie diaocha zhi shengnü de zibaishu" (Jiayuan.com.cn published a survey on men and women's attitudes towards marriage: The Monologue of the Shengnü Ladies), 360doc, available at: http://www.360doc.com/content/12/0309/1 4/1118998_192998124.shtml (accessed 11.03.2012).

Fincher, Leta Hong (2015), Leftover Women: The Resurgence of Gender Inequality in China, London and New York: Zed Books.

Fisher, Burton (2004), Puccini's Operas: The Glorious Dozens, Boca Raton: Opera Journeys Publishing.

Flynn, Mark A., Clay M. Craig, Christina N. Anderson, and Kyle J. Holody (2016), "Objectification in Popular Music Lyrics: An Examination of Gender and Genre Differences", Sex Roles 75: 164-176.

Foucault, Michel (1997), "Of Other Spaces: Utopias and Heterotopias", 350-336, in Neil Leach (ed.), Rethinking Architecture: A Reader in Cultural Theory, 
New York: Routledge.

Frith, Simon (1996), Performing Rites: On the Value of Popular Music, Cambridge, Mass.: Harvard University Press.

Fu, Guangming (2007), "Xin wuxia wenxue wushinian huigu" (A review of new martial novels in the past fifty years), Sina.com, available at: http://vip.book.sina.com.cn/book/chapter_42975_28230.html (accessed 18. 01.2011).

Fung, Anthony and Michael Curtin (2002), "The Anomality of Being Fay (Wong): Gender Politics in Chinese Popular Music", International Journal of Cultural Studies 5(3): 263-290.

Furedi, Frank (2004), Where Have All Intellectuals Gone?, London: Continuum.

Gaetano, Arianne M. (2015), Out to Work: Migration, Gender, and the Changing Lives of Rural Women in Contemporary China, Honolulu: University of Hawaii Press.

- - (2014), “'Leftover Women': Postponing Marriage and Renegotiating Womanhood in Urban China", Journal of Research in Gender Studies 4(2): 120-149.

Gongfu, Naicha (2011), “Dang nanren yudao nüren” (When men meet women), Shaoxing Ewang Luntan, available at: http://www.e0575.cn/read.ph p?tid=3426503 (accessed 03.01.2012).

Gong, Wanqi, Guo Qin and Jiang Crystal Li (2018), "Zhongguo danshen nüxing de kunjing: duoyuan jiaocha de shehui yali he qishi" (The dilemma of Chinese single women: understanding oppression and discrimination from an intersectional perspective), Journal of Zhejiang University (Humanities and Social Sciences Online Edition) 4(2): 117-128.

Gottlieb, Roger S. (1989), An Anthology of Western Marxism: From Lukács to Gramsci to Socialist-Feminism, New York and Oxford: Oxford University Press.

Gu, Changwei (dir.) (2007), Lichun (And the spring comes), Beijing: Poly-Huayi 
Media of China, 105 mins.

Holmes, Su and Diane Negra (eds.) (2011), In the Limelight and Under the Microscope: Forms and Functions of Female Celebrity, New York: Continuum. Huang, Kuanwei (2011), Bodao jianyi nükaosheng kaobo qian tan lianai: jiejue buhao yingxiang xuexi (PhD supervisor suggested his $\mathrm{PhD}$ candidates to settle a stable romantic relationship before taking the doctoral selection exams: celibacy will be a negative impact in their academic life), Guangzhou Daily, available at: https://news.qq.com/a/20110806/000098. htm (accessed 19.08.2011).

Hui, Ann (dir.) (2006), Yima de houxiandai shenghuo (The postmodern life of my aunt), Hong Kong: Universal Laser \& Video Co., Ltd. 111 mins.

Irigaray, Luce (1985), This Sex Which is Not One, Ithaca and New York: Cornell University Press.

Iwabuchi, Koichi, Eva Tsai and Chris Berry (eds.) (2017), Routledge Handbook of East Asian Popular Culture, Abingdon: Taylor and Francis.

Jameson, Fredric (2013), Postmodernism, Or, The Cultural Logic of Late Capitalism, Durham: Duke University Press.

Jiang, Cristal L. and Wanqi Gong (2016), “Counteracting Indirect Influence: the Responses of Single Chinese Women in to Prejudicial Media Portrayals of Single Womanhood", Chinese Journal of Communication 9(3): 215-231.

Jiang, Ning and Niu Yajun (2008), "Yuyan shishi de xingbie weikun: quanli huayu xia de "disanxing'" (Gender connotation in the use of language: the 'third sex' under the power of language), Collection of Women's Studies 3 (86): 45-58

Ka, Nong (2017), "Na jige shangguo Meng Fei Feicheng wurao de nüboshi, tamen dou zhaodao duixiang le ma?" (Did the female PhDs in If You Are the One find their $\mathrm{Mr}$ Right?), sohu.com, available at: http://www.sohu.com/a/192699906_99973820 (accessed10.05.2018). KKNews (2017a), "Zuo yi zhi teli duxing de zhu, ye yu shisu woshou yenhe" (As a 
maverick pig, you'll shake hands and talk with the secular world), KKNews.com, available at: https://kknews.cc/entertainment/5xbl2b3.html (accessed 22.01.2019).

KKNews (2017b), "Chuntian yilai, wo de xin zongshi chunchun yudong, zhe bu ju chule xing, haiyou mengxiang he qinghuai" (When the spring comes my heart becomes restless; this drama, apart from sex, also has dreams and feeling), KKNews.com, available at: https://kknews.cc/entertainment/v94n 6m4.html (accessed 22.01.2019).

KKNews (2018), “Jintian lichun, Jiang Wenli ye yanguo yi bu jiao 'Lichun' de dianying, shi ta zui keai de juese" (Today, in the spring, Jiang Wenli has also acted in a film called 'And the Spring Comes', which is her most loveable role), KKNews.com, available at: https://kknews.cc/entertainment/4ervnx 2.html (accessed: 22.01.2019).

Ko, Dorothy (1994), Teachers of the Inner Chambers: Women and Culture in Seventeenth-century China, Stanford: Stanford University Press.

Kong, Shuyu (2014), Popular Media, Social Media and Public Discourse in Contemporary China, London: Routledge.

Kostagiolas, Petros, Konstantina Matzoukou, Charilaos Lavranos (eds.) (2016), Trends in Music Information Seeking, Behavior and Retrieval for Creativity, Hershey: Information Science Reference.

Kristeva, Julia (1975), "On the Women of China”, trans. by Ellen Conroy Kennedy, Signs 1(1): 57-81.

Lake, Rosanne (2012), "All the Shengnu Ladies", Salon, available at: http://www.salon.com/2012/03/12/all_the_shengnu_ladies/ (accessed 17.03. 2012).

Lam, Jeffie (2018), "Where are all the Women? 4 in 5 Senior Academics at Hong Kong's Publicly Funded Universities are Men", South China Morning Post, available at: https://www.scmp.com/news/hong-kong/education/ article/2165396/where-are-all-women-4-5-senior-academics-hong-kongs 
(accessed 28.09.2018).

Leymarie, Michel and Jean-Francois Sirinelli (2007), Xifang dangdai zhishifenzi shi (L'histoire des intellectuels aujourd'hui), trans. by Gu Yuanfen, Nanjing: Jiangsu jiaoyu chubanshe.

Li, Meng (2013), “Estrangement and Escape: A Feminist Thematic Analysis of the Representations of Intellectual Women in Huang Beijia's Novellas (19801994)", unpublished PhD thesis, University of Sydney.

- - (2013), "Estrangement: A Possible Lens in Understanding the Femininity of Post-Mao Intellectual Women", Frontiers of Literary Studies in China, High Education Press and Springer 7(1):87-116.

Li, Xiaojiang (2016), Nüxing wutuobang (Women's utopia), Beijing: Social Sciences Academic Press (China).

Li, Xiaojiang and Zhang Xiaodan (1994), “Creating a Space for Women: Women's Studies in China in the 1980s", Signs 20(1): 137-151.

Liu, Jinping (re-poster) (2011), "You ren zai yaomohua nü boshi (you tu)" (Again someone is demonising female PhDs (with picture)), Sciencenet.cn, available at: http://wap.sciencenet.cn/blog-39731-522688.html?mobile=1 (accessed 22.01.2019).

Liu, Ling and Zhu Yanxin (2009), "Weihun danshen nüboshi hunlianguan diaocha: jiyu dui wuwei nüxing boshi yanjiusheng de fangtan" (The attitudes of unmarried female PhD candidates towards romance and marriage-A study based on interviews with 5 female PhD candidates), China Journal of Health Psychology 17(5): 714-716.

Long, Imogen (2013), Women Intellectuals in Post-68 France: Petitions and Polemics, Basingtoke: Palgrave Macmillan.

Lu, Tonglin (1995), Misogyny, Cultural Nihilism and Oppositional Politics: Contemporary Chinese Experimental Fiction, Stanford: Stanford University Press.

Lu, Zhanyuan (2012), "Yizhangtu: dang nanren yudao nüren, nüboshi liangle" 
(When man meets woman. What happens to the women PhDs?), Baidu, available at: https://tieba.baidu.com/p/1380392616?red_tag=047973931 0 (accessed 13.02.2012).

Lu, Zhenglan (2017), "The Anxiety of Love: An Analysis of Recent Chinese Popular Music", Social Semiotics, available at: http://www.tandfonline.com/doi/full/10.1080/10350330.2017.1381467 (accessed 28.10.2017).

Luo, Aiping, Wang Feng and Jiang Yu (2014), Zhongguo shengnü diaocha (Survey on Chinese leftover women), Guangzhou: Guangdong renmin chubanshe.

Luo, Wei and Zhen Sun (2015), “Are You the One? China' TV Dating Shows and the Sheng Nü's Predicament", Feminist Media Studies 15(2): 239-256.

Luo, Xin (2016), "Guonei shuju diaocha: xingbie qieshi daozhi xueshuquan nüxing liushi" (Data survey in Mainland China: gender discrimination led to the drainage of women in academia), The Paper, available at: http://www.thepaper.cn/newsDetail_forward_1416052 (accessed 07.10. 2017).

Ma, Lilingshan (2012), "Shao Yibei: qu ni de xiao qingxin" (Shao Yibei: fuck off you hipsters), Southern People Weekly 3: 96-97.

Mann, Susan and Cheng Yu-yin (eds.) (2001), Under Confucian Eyes: Writings on Gender in Chinese History, Berkeley, Los Angeles and London: University of California Press.

Mannheim, Karl (1992), "The Problem of the Intelligentsia, An Enquiry into its Past and Present Role", 91-170, in Bryan S. Turner (ed.), Essays on the Sociology of Culture, London, New York: Routledge.

- - (1960), Ideology and Utopia: An Introduction to the Sociology of Knowledge, London: Routledge and Kegan Paul.

Marchetti, Gina (2009), “Gender Politics and Neoliberalism in China: Ann Hui's the Postmodern Life of My Aunt", Visual Anthropology 22(2-3): 123-140.

Mendel, Iris (2006), “Mannheim's Free-Floating Intelligentsia: The Role of 
Closeness and Distance in the Analysis of Society", Studies in Social and Political Thought March (12): 30-52.

Mok, Ka-ho (1998), Intellectuals and the State in Post-Mao China, London: MacMillan Press.

Murray, Jeremy and Kathleen Nadeau (eds.) (2016), Pop Culture in Asia and Oceania, Santa Barbara: ABC-CLIO.

Nelson, Deborah (2017), Tough Enough: Arbus, Arendt, Didion, McCarthy, Sontag, Weil, Chicago and London: The University of Chicago Press.

Pels, Dick (2013), The Intellectual as Stranger: Studies in Spokespersonship, London: Routledge.

Qian Yue (2017), "Yiwei 'jianchi zou keyan daolu' nü xuezhe de zibai" (Monologue of a women scholar who persists in being an academic), MsMuses, available at: https://mp.weixin.qq.com/s/j0Y5nLSO16kF_Dx8U KRB9 (accessed 07.10.2017).

Said, Edward W. (1994), Representations of the Intellectuals: The 1993 Reith Lectures, New York: Pantheon Books.

Sartre, Jean-Paul (1955), No Exit and Three Other Plays, New York: Vintage Books. Shao, Yibei (2009), "Shao Yibei: Daling wenyi nüqingnian zhi ge" (Shao Yibei: Song of an Elder Artistic Women), Youtube.com, available at: https://www.youtube.com/watch?v=Obk8VzwLncA (accessed 02.01.2011). Sharp, Elizabeth A. and Lawrence Ganong (2011), "'I'm a Loser, I'm Not Married, Let's Just All Look at Me': Ever-Single Women's Perceptions of Their Social Environment", Journal of Family Issues 32(7): 956-980.

Shen, Alice (2018), "The Gender Imbalance in China's PhD studies: Why Women Make Up Only a Third of the Cohort", South China Morning Post, available at: https://www.scmp.com/news/china/society/article/2159295/ genderimbalance-chinas-phd-studies-why-women-make-only-third (accessed 28.09.2018).

Shenzhen Wanbao (2012), "Shishang sanba jie: shengnü busheng" (A trendy way 
to celebrate Women's Day: be a blossoming woman rather than a leftover woman), Sohu, available at: http://roll.sohu.com/20120308/n337 072327.shtml (accessed 11.03.2012).

Sina (2008), "Ziliao: Gu Changwei xin pian 'Lichun' juzhao (6)" (Information: still (6) from Gu Changwei's new film 'And the Spring Comes'), Sina, available at: http://ent.sina.com.cn/d/2008-01-18/14051882880.shtml (accessed 22.01.2019).

Siu, Helen F. (2016), Tracing China: A Forty-Year Ethnographic Journey, Hong Kong: Hong Kong University Press.

Sohu.com (2007), "Yu Yima ze 'fa'-'Yima de houxiandai shenghuo' huanyu san qu DVD" (Encountering the aunt issued-'The Postmodern Life of My Aunt' global region 3 DVD, Sohu.com, available at: (accessed:22.01.2019).

Sowell, Thomas (2009), Intellectuals and Society, New York: Basic Books. Spakowski, Nicola (2018), "Dreaming a Future for China: Visions of Socialism among Chinese Intellectuals in the Early 1930s", Modern China 45(1): 91122.

The State Language and Writing Commission, Minister of Education of the People's Republic of China (2007), Zhongguo yuyan shenghuo zhuangkuang baogao (2006) (Report on the Chinese Language in the Year 2006), Beijing: Ministry of Education of the People's Republic of China.

To, Sandy (2013), “Understanding Sheng Nu ('Leftover Women'): the Phenomenon of Late Marriage among Chinese Professional Women", Symbolic Interaction 36(1): 1-20.

-- (2015), China's Leftover Women: Late Marriage Among Professional Women and its Consequences, London and New York: Routledge, 2015.

Tong, Xin (2008), "Sanshi nian Zhongguo nüxing/xingbie shehuixue yanjiu" (Thirty years of women/gender studies in China), Collections of Women's Studies 3(86):66-74.

Tuana, Nancy (1983), The Less Noble Sex: Scientific Religious and Philosophical 
Concepts of Women's Nature, Bloomington and Indianapolis: Indiana University Press.

U, Eddy (2007), "The Making of Chinese Intellectuals: Representations and Organization in the Thought Reform Campaign", The China Quarterly 192: 971-989.

- - (2009), "Reification of the Chinese Intellectual: On the Origins of the CCP Concept of 'Zhishifenzi'", Modern China 35(6): 604-631.

- - (2013), "Reifications of Intellectual: Representations, Organization and Agency in Revolutionary China", The British Journal of Sociology 64(4): 617642.

Ueno, Chizuko (2015), Yan nü: riben de nü xing xianwu (Misogyny: hatred against women in Japan), trans. by Steve Yang, Taipei: Unitas Publishing Co. Ltd.

Wang, Esther (2018), “Feminism As a 'Global Solidarity Movement': Leta Hong Fincher on Feminism and \#MeToo in China", Jezebel, available at: https://jezebel.com/feminism-as-a-global-solidarity-movement-leta-hongfin-1829180875 (accessed 28.09.2018).

Wang Hansen (2012), "Nüboshi shi cong putao dao putaogan de guocheng" (The process of becoming a women $\mathrm{PhD}$ is comparable to that of turning fresh grapes into raisins), Sciencenet, available at: http://bbs.sciencenet.cn/home.php?mod=space \&uid=5414\&do=blog\&id= 535619 (accessed 07.02.2012).

Wang, Liming, Tang Fuchou, Dong Yige and Chen Xiaoxue (2015), "Guonei xueshu jigou xingbie wenti diaocha wenjuan" (Online survey on gender issues within Mainland Chinese academic institutes), Chuansongmen, available at: http://chuansong.me/n/2349806 (accessed 27.10.2017).

Wang, Ning (2017), "Bowing to Chairman Mao: Western-Trained Intellectuals and the State in the Early PRC", Journal of Contemporary China 27: 110, 312326.

Wang, Zheng (2017), A Socialist Feminist Revolution in the People's Republic of 
China: 1949-1964, Oakland: University of California Press.

Wang, Zheng and Lü Xinyu (eds.) (2016), Xingbie yu shijue: bainian zhongguo yingxiang yanjiu (Gender and visuality: studies of Chinese visual images of the past century), Shanghai: Fudan daxue chubanshe.

Weininger, Otto (1906), Sex and Character, New York and Chicago: A.L. Burt Company.

Weili (2009), "Shiji jiayuan Gong Haiyan: shengnü qishishi 'shengnü'”(Gong Haiyan of Jiayuan.com says: leftover women are actually women of victory), qq.com, available at: http://tech.qq.com/a/20090424/00044 6.htm (accessed 10.05.2018).

White, Lynn T. (1998), Unstately Power: Local Causes of China's Economic Reforms, New York: M.E. Sharpe.

Xiari Qiangwei (2015), "Meige wenyi qingnian doushi Wang Cailing" (Every artistic youth can call him/herself Wang Cailing), blog.sina.cn, available at: http://blog.sina.com.cn/s/blog_3e4864c40102vh5a.html (accessed 10.05. 2018)

Xu, Jilin (2016), Zhongguo zhishifenzi shilun (Ten essays on Chinese intellectuals), Hong Kong: Hong Kong Open Page Publishing Co.Ltd.

Xu, Youyu (2014), "Intellectual Discourses in Post-Mao China and Today", China Change, available at: https://chinachange.org/2014/05/12/defiance/ (accessed 04.05.2018).

Yang, Xiaobing (2002), The Chinese Postmodern: Trauma and Irony in Chinese Avant-Garde Fictions, Ann Arbor: The University of Michigan Press.

Ye, Zi (ed.) (2010), "Nüboshi: women bushi miejue shitai” (Female doctoral students: we are not destructive nuns), China.com, available at: http://www.china.com.cn/info/dress/2011-09/04/content_23348771.htm (accessed 28.03.2012).

Yu, Ying-shih (2003), "Zhongguo zhishifenzi de bianyuanhua" (The marginalisation of Chinese intellectuals), $21^{\text {st }}$ Century (online edition) 6(13): 
available at: http://www.cuhk.edu.hk/ics/21c/media/online/9100057.pdf (accessed 06.05.2018).

-- (2014), "Fanzhilun yu Zhongguo zhengzhi chuantong: lun ru, dao, fa sanjia de zhengzhi sixiang fenye yu huiliu" (Anti-intellectualism and the tradition of politics in China: on the difference and convergence of political thought in Confucianism, Taoism and Legalism), in Lishi yu sixiang, Taipei: Linking Books.

Yu Zhongli (2015), Translating Feminism in China: Gender, Sexuality and Censorship, London and New York: Routledge.

Zhang, Qian and Li Xiaopan (2018), "Nüxing dubo jia shengwa, liangquan or jiongtu?" (Can women handle child-rearing and doctoral research at the same time?), Chinese Youth Online, available at: http://zqb.cyol.com/html/ 2018-09/17/nw.D110000zgqnb_20180917_1-09.htm (accessed 19.09. 2018).

Zhao, Jin (2011), "Holy Goddess of China Trampling Men and Singing Too", Things You Don't Know about China, available at: http://thingsyoudontkno waboutchina.com/2011/05/12/holy-goddesses-of-china-trampling-menand-singing-too/ (accessed 17.03.2012).

Zhong, Xueping, Wang Zheng and Bai Di (eds.) (2001), Some of Us: Chinese Women Growing Up in the Mao Era, New Brunswick: Rutgers University Press.

Meng $\mathbf{L} \mathbf{i}$ is a Teaching Fellow at the Confucius Institute of Hong Kong, in the Faculty of Humanities at the Hong Kong Polytechnic University. 